quills edged with brownish-white, the two outer tail-feathers with a white patch on the inner web; the lower parts dull white, tinged on the neck with yellow, on the sides with greyish-brown.

Male, $5 \frac{1}{2}, 8 \frac{1}{2}$.

Middle districts. Rather common. Migratory.

\title{
The Dwarf Maple.
}

\section{Acer spicatum.}

This is a low shrubby tree, which does not attain a greater height at most than fifteen or twenty feet. It abounds along the rocky margins of creeks or rivers, especially those meandering at the bases of the Alleghany mountains.

\section{BLACK-THROATED GREEN WOOD-WARBLER.}

+ Sylvicola virens, Lath.

PLATE LXXXIV.-Male and Female.

I have traced this species from the Texas to Newfoundland, although at considerable intervals, along our Atlantic coasts, it being of rare occurrence or wanting in some parts, while in others it is abundant; but in no portion of the United States have I met with it so plentiful as around Eastport in Maine, where I saw it in the month of May. Many remain all summer in that State, as well as in Massachusetts, and the northern parts of New York; and some are found at that season even in the higher portions of Pennsylvania. On the coast of Labrador it was not observed by me or any of my party, and it is not mentioned by Dr. Richardson as having been seen in the Fur Countries. Its habits are intermediate between those of many of our Warblers and the Vireos, the notes of which latter it in a great measure assumes. It usually makes its appearance in Maryland and New Jersey about the first week of May, when it is observed to be actively engaged in searching for food, regardless as it were of the presence of man. Its movements when proceeding northward are rapid, and it advances through the woods solitarily or nearly so, it being seldom that more than two or three are found together at this time, or indeed during the breeding season, at which period each pair appropriates to itself a certain extent of ground. Its retrograde 


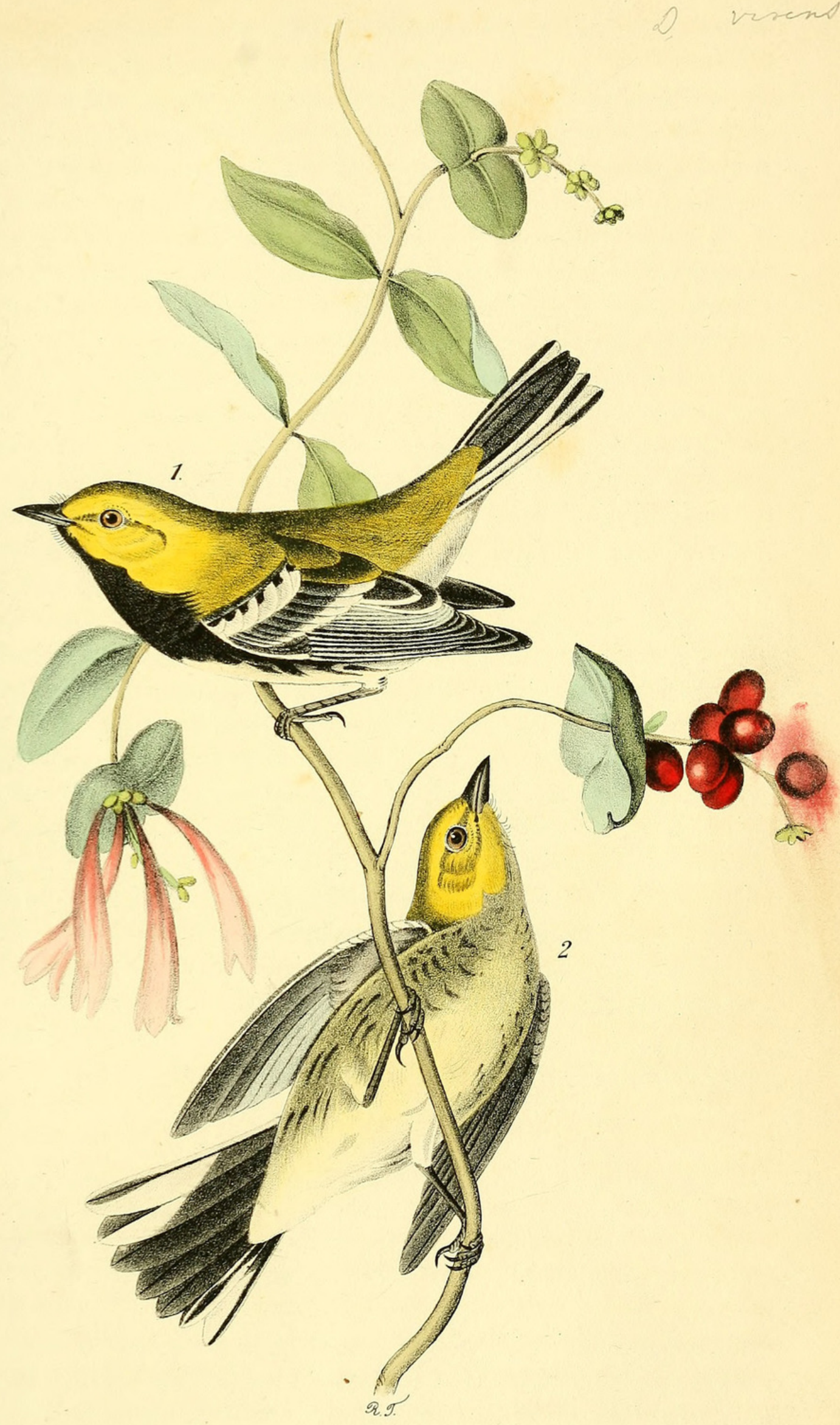

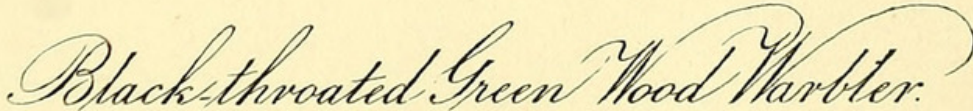

$$
\text { Couprefotium Cempervirions }
$$



march is also rapid, and by the middle of October they all seem to have passed beyond the limits of our most southern States.

The food of this species consists during the summer months of various kinds of flies and caterpillars, many of the former of which it captures by darting after them from its perch, in the manner of Flycatchers and Vireos, emitting like them also a clicking sound from its bill. In the autumn it is often seen feeding on small berries of various sorts, in which respect also it resembles the birds just mentioned. I never found the nest of this bird, of which, however, Mr. Nurtall has given a minute description, which I shall here, with his permission, place before you. "Last summer (1830), on the 8 th of June, I was so fortunate as to find a nest of this species in a perfectly solitary situation, on the Blue Hills of Milton. The female was now sitting, and about to hatch. The nest was in a low, thick, and stunted Virginia juniper. When I approached near to the nest, the female stood motionless on its edge, and peeped down in such a manner that I imagined her to be a young bird; she then darted directly to the earth and ran, but when, deceived, I sought her on the ground, she had very expertly disappeared; and I now found the nest to contain four roundish eggs, white, inclining to flesh-colour, variegated, more particularly at the great end, with pale purplish points of various sizes, interspersed with other large spots of brown and blackish. The nest was formed of circularly entwined fine stripes of the inner bark of the juniper, and the tough white fibrous bark of some other plant, then bedded with soft feathers of the Robin, and lined with a few horse hairs, and some slender tops of bent grass ( Agrostis)."

My friend describes the notes of this species as follows:- "This simple, rather drawling, and somewhat plaintive song, uttered at short intervals, resembles the syllables 'te de' territica, sometimes tederisca, pronounced pretty loud and slow, and the tones proceeding from high to low." These notes I am well acquainted with, but none can describe the songs of our different species like Nuttall.

I have represented the male and female; the latter, I believe, has not been hitherto figured.

Black-throated Green Warbler, Sylvia virens, Wils. Amer. Orn., vol. ii. p. 127.

Sylvia virens, Bonap. Syn., p. 80.

Black-throated Green Warbler, Nutt. Man., vol. i. p. 376.

Black-throated Green Warbler, Sylvia virens, Aud. Orn. Biog., vol. iv. p. 70.

Outer three quills almost equal, second very slightly longer; tail slightly emarginate. Male with the upper parts very light yellowish-green; the anterior part of the forehead, a band over the eye, the cheeks, and the sides of 
the neck bright yellow; the fore part of the neck, anterior part of the sides, and some spots on the hind parts of the latter, black; the rest of the lower parts white, partially tinged with yellow; quills and tail-feathers brownishblack; secondary coverts and first row of small coverts largely tipped with white, quills margined with greyish-white, as are the tail-feathers, of which the greater part of the outer three, and a patch on the inner web of the fourth, are white. Female with the upper parts similar, but with less yellow on the forehead; ear-coverts greenish; the yellow band over the eye less bright, the yellow on the sides of the neck of less extent; the lower parts dull yellowishwhite, the sides streaked with dusky.

Male, $4 \frac{1}{1} \frac{0}{2}$, wing, $2 \frac{1}{2}$. Female, $4 \frac{1}{2}$, wing, $2 \frac{5 \frac{1}{2}}{2}$.

From Texas to Newfoundland. Abundant. Migratory.

\title{
C A PE MA Y W O OD-W A R BLER.
}

\author{
+Sxlvicola maritima, Wils.
}

PLATE LXXXV.-Male and Female.

Of this beautiful species, which was first described by WILson, very little is known. It seems to pass rapidly through our Middle Districts in May. I have never met with a single bird of this kind on my rambles, and am indebted for the fine specimens of both sexes in my possession, and from which I drew the figures in the plate, to my generous friend EDward Harris, Esq. of Moorestown, New Jersey, who procured them, with several others, in that district.

C $_{\text {APE }} \mathrm{M}_{\mathrm{Ay}} \mathrm{W}_{\mathrm{ARble}}$, Sylvia maritima, Wils. Amer. Orn., vol. iv. p. 99.

Sylvia maritima, Bonap. Syn., p. 79.

$\mathrm{C}_{\mathrm{APE}} \mathrm{M}_{A \mathrm{Y}} \mathrm{W}_{\mathrm{ARBleR}}$, Sylvia maritima, Nutt. Man., vol. i. p. 156.

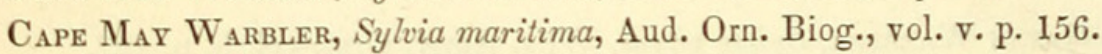

Wings pointed, first quill longest, the second a quarter of a twelfth shorter, the third a twelfth shorter; tail slightly emarginate. Male with the upper part of the head and fore part of the back yellowish-olive, streaked with black; the rump, throat, and a collar scarcely meeting behind, yellow; earcoverts and a band over the eye yellowish-red, loral space paler; a white patch on the wing, formed by the first row of small coverts and the outer 


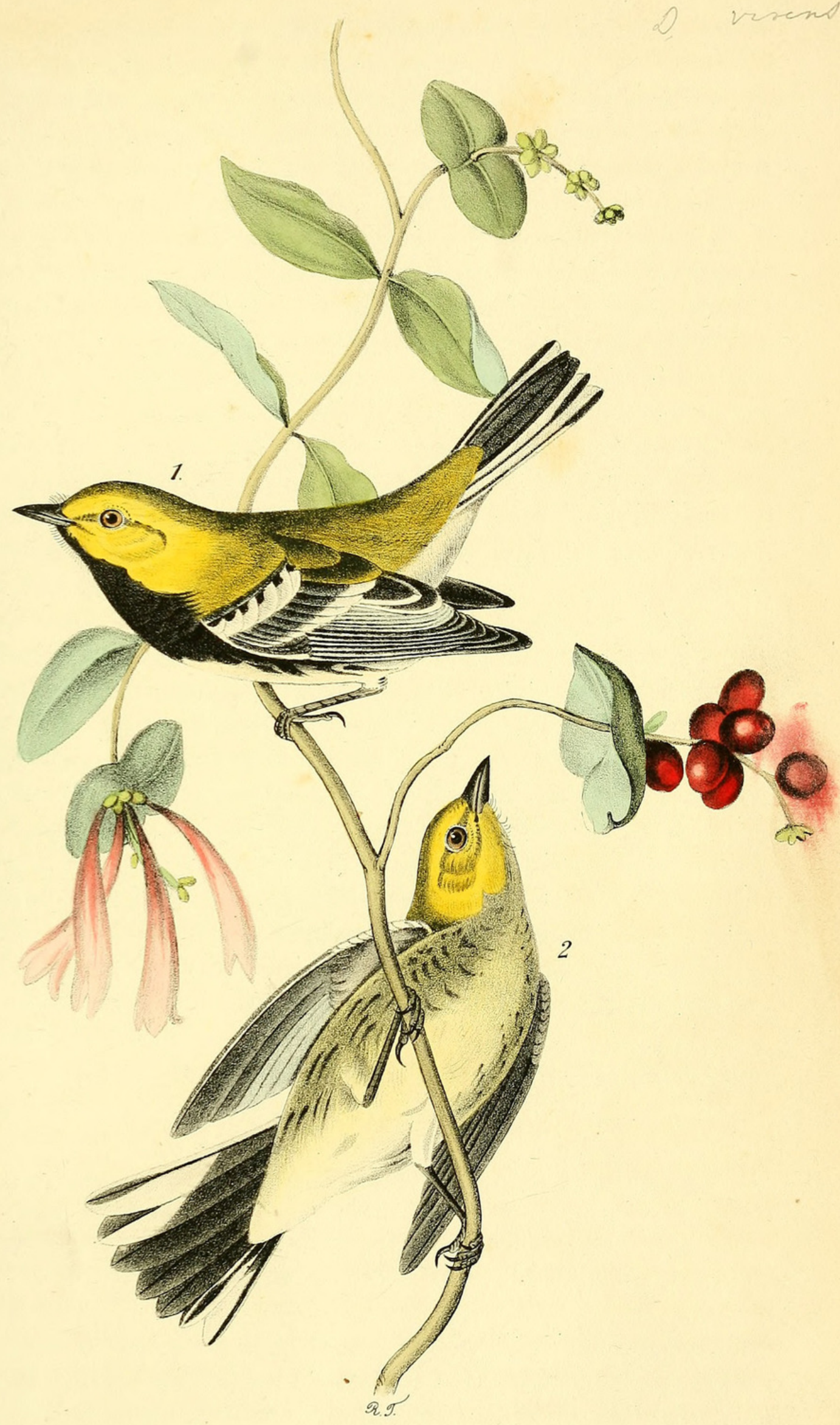

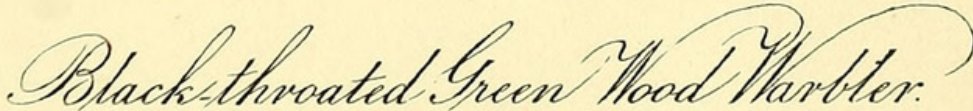

$$
\text { Couprefotium Cempervirions }
$$




\section{$2 \mathrm{BHL}$ Biodiversity Heritage Library}

Audubon, John James. 1841. "The Black-Throated Green Wood-Warbler, Sylvicola virens, Lath. [PI. 84]." The birds of America : from drawings made in the United States and their territories 2, 42-44. https://doi.org/10.5962/p.319197.

View This Item Online: https://www.biodiversitylibrary.org/item/124834

DOI: https://doi.org/10.5962/p.319197

Permalink: https://www.biodiversitylibrary.org/partpdf/319197

\section{Holding Institution}

Smithsonian Libraries

\section{Sponsored by}

Biodiversity Heritage Library

\section{Copyright \& Reuse}

Copyright Status: NOT_IN_COPYRIGHT

This document was created from content at the Biodiversity Heritage Library, the world's largest open access digital library for biodiversity literature and archives. Visit BHL at https://www.biodiversitylibrary.org. 